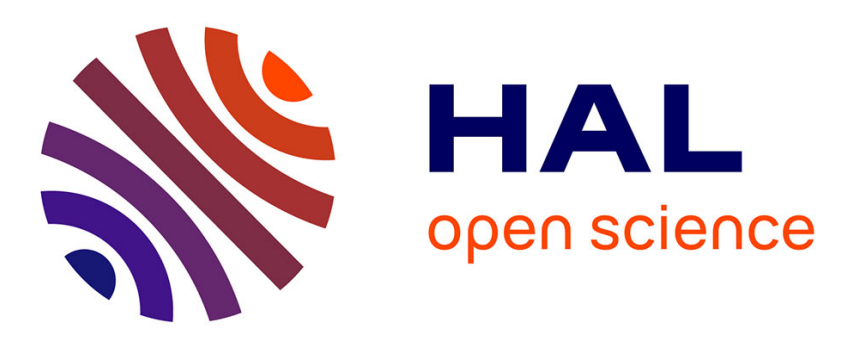

\title{
ON THE EFFECT OF HIGH PRESSURES ON THE MOBILITY OF ATOMS IN GRAIN BOUNDARIES
}

W. Lojkowski

\section{To cite this version:}

W. Lojkowski. ON THE EFFECT OF HIGH PRESSURES ON THE MOBILITY OF ATOMS

IN GRAIN BOUNDARIES. Journal de Physique Colloques, 1988, 49 (C5), pp.C5-545-C5-549. 10.1051/jphyscol:1988566 . jpa-00228063

\section{HAL Id: jpa-00228063 https://hal.science/jpa-00228063}

Submitted on 1 Jan 1988

HAL is a multi-disciplinary open access archive for the deposit and dissemination of scientific research documents, whether they are published or not. The documents may come from teaching and research institutions in France or abroad, or from public or private research centers.
L'archive ouverte pluridisciplinaire HAL, est destinée au dépôt et à la diffusion de documents scientifiques de niveau recherche, publiés ou non, émanant des établissements d'enseignement et de recherche français ou étrangers, des laboratoires publics ou privés. 


\title{
ON THE EFFECT OF HIGH PRESSURES ON THE MOBILITY OF ATOMS IN GRAIN BOUNDARIES
}

\author{
W. LOJKOWSKI
}

UNIPRESS, High Pressure Research Center, Polish Academy of Sciences, Sokolowska 29, PL-01-142 Warsaw, Poland

\begin{abstract}
Abstrast
The results of recent investigations of the effect of high pressures on grain boundary diffuston and grain boundary migration in Aluminium are compared. The activation volume for general grain boundaries migration was found to be less than $0.2 \Omega(\Omega$ - atomic volume). On the other hand the activation volume for diffusion along general boundaries and subboundaries is close to $0.8 \Omega$. A similar value for $\Omega$ was obtained for migration of subboundaries. It follows that the formation volume for defects controling atomic mobility across general boundaries is significantly less than of those controliing diffusion along boundaries and dislocation climb.
\end{abstract}

\section{Introduction}

Investigations of diffusion mechanisms by means of high pressure methods have a long tradition (see for instance ref. 1). The advantage of measurements of the effect of high pressure on diffusion is that it allows to determine the changes of the volume of the investigated body due to the creation and motion of defects controlling the diffusion kinetics. The basic equation in that respect is ( 1 ):

$$
\left.V^{*}:=-R T(\langle\delta \ln D) / \delta \mathrm{p})_{\mathrm{T}}-\left(\delta \log \mathrm{D}_{-} / \delta \mathrm{p}\right)_{\mathrm{T}}\right\}
$$

where: $V$ is the activation volume, $\mathbb{R}$ - gas constant, $T$ - temperature, p - pressure, $D$ - diffusion coefficient, $D=D_{0} \exp (-G / R T), G$ - Gibbs free energy of activation for diffusion.

An identical in form as above equation can be applied to grain boundary migration processes.

Knowing the activation valume, it is possible to draw conclusions concerning the mechanisms of the thermally activated processes investigated. However, only few results concerning high pressure investigations of the mechanisms of thermally activated atomic mobility in grain boundaries were reported (2,3). This concerns both grain boundary migration (GBM) (2) and grain boundary diffusion (GBD) (3). The purpose of the present paper is to compare some recent results of investigations of the effect of high pressure on both GBM and GBD in the same material, alumintum. 
Investigations of the effect of high pressure on GBM in Aluminium (4)

The details of the experiments are reported elsewhere (4) therefore here only a brief account of the experimental methods will be given. Aluminium rods of $4 N$ purity were hydrostatically extruded so that their diameter was reduced from $30 \mathrm{~mm}$ to $3 \mathrm{~mm}$. Further, one group of aluminium rods was annealed under pressures up to $1 \mathrm{GPa}$ at the temperature of $453 \mathrm{~K}$ for one hour. It is known (5) that such a treatment at normal pressure leads to an "In-situ" recrystallization, not by movement of high angle, general boundaries, but by absorption of some subboundaries by other subboundaries. Therefore, the effect of high pressure on the rate of dislocation climb and subboundaries migration could be established.

Another group of specimens was fully recrystallized at $623 \mathrm{~K}$ and subsequently annealed under high pressures. Afterwards, the effect of high pressure on the final grain size was measured. As the grain size is proportional to the grain boundary migration rate, this enabled the activation volume for migration of general boundaries to be assessed. The annealing treatments and the effect of high pressure on the grain size are given in tab. 1 .

Table.1. The effect of annealing temperature and pressure on the grain size of aluminium after strong deformation

\begin{tabular}{|c|c|c|c|c|c|c|c|c|c|c|}
\hline 1 & & 1 & & & 1 & & 1 & & & \\
\hline $\begin{array}{l}1 \\
1\end{array}$ & specimen & $\begin{array}{l}1 \\
1\end{array}$ & Thermal & treatment & $\begin{array}{l}1 \\
1\end{array}$ & $\begin{array}{l}\text { pressure } \\
\text { (GPa) }\end{array}$ & 1 & grain size & $(\mu \mathrm{m})$ & I \\
\hline 1 & & 1 & & & I & & 1 & & & 1 \\
\hline 1 & A & 1 & $553 \mathrm{~K} / 1$ & hour & 1 & 0.05 & 1 & $3.1+1-0.5$ & & 1 \\
\hline 1 & B & 1 & $553 \mathrm{~K} / 1$ & hour & 1 & 1 & । & $3.1+/-0.6$ & * & 1 \\
\hline 1 & C & 1 & $553 \mathrm{~K} / 8$ & hours & 1 & 1 & 1 & $4.2+/-1.0$ & & 1 \\
\hline 1 & & 1 & & & 1 & & 1 & & & 1 \\
\hline 1 & & 1 & & & I & & 1 & & & 1 \\
\hline 1 & $\mathrm{D}$ & 1 & $553 \mathrm{~K} / 1$ & hour & 1 & 0 & 1 & 3.1 & & 1 \\
\hline 1 & & 1 & $623 \mathrm{~K} / 1$ & hour & 1 & 0.05 & 1 & 52 & & 1 \\
\hline 1 & $\mathbf{E}$ & 1 & $553 \mathrm{~K} / 1$ & hour & 1 & 0 & 1 & 3.2 & & 1 \\
\hline 1 & & 1 & $623 \mathrm{~K} / 1$ & hour & 1 & 0.5 & 1 & 54 & & 1 \\
\hline 1 & $\mathrm{~F}$ & 1 & $553 \mathrm{~K} / 1$ & hour & 1 & $\theta$ & 1 & 3.0 & & 1 \\
\hline 1 & & 1 & $623 \mathrm{~K} / 1$ & hour & 1 & 1.0 & 1 & 36 & & I \\
\hline 1 & & 1 & & & 1 & & 1 & & & 1 \\
\hline
\end{tabular}

not fully recrystallized material

The above results show that the grain growth is not measurably affected by increasing the pressure of annealing. The activation volume for grain growth, 1.e, GBM, was assessed as $V^{*} \leqslant 0.2 \Omega(4)$. However, increasing the pressure strongly affected the recrystallization process. In order to achieve a fully recrystallized structure, it was necessary to increase the time of annealing to 8 hours.

Besides grain size determination, mechanical tests of the annealed specimens were carried out (fig.1). Mechanical tests are more suitable than grain size measurements when microstructure transformations of partiy recrystalilized specimens have to be assessed. In fact, the mechanical tests have shown that the yield stress of specimen $B$ is by $30 \%$ higher than for specimen A. However, the specimen $C$, annealed under the same pressure as specimen $B$ but for a time of 8 hours, has identical mechanical properties as specimen $A, i . e$, has a comparable microstructure. The above measurements allow to asses the activation volume for processes of dislocation climb and low angle grain boundary migration as $V * 0.8 \Omega$ (4). 


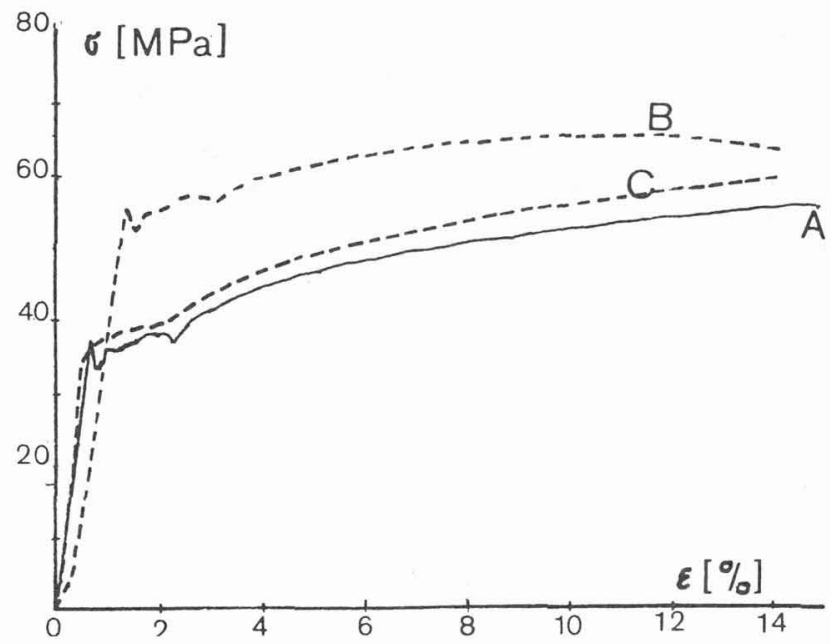

Fig. 1 Yield stress as a function of true strain for aluminium specimens recrystallized under high pressure (after ref.4). Annealing temperature, pressures and times are given in tab. 1

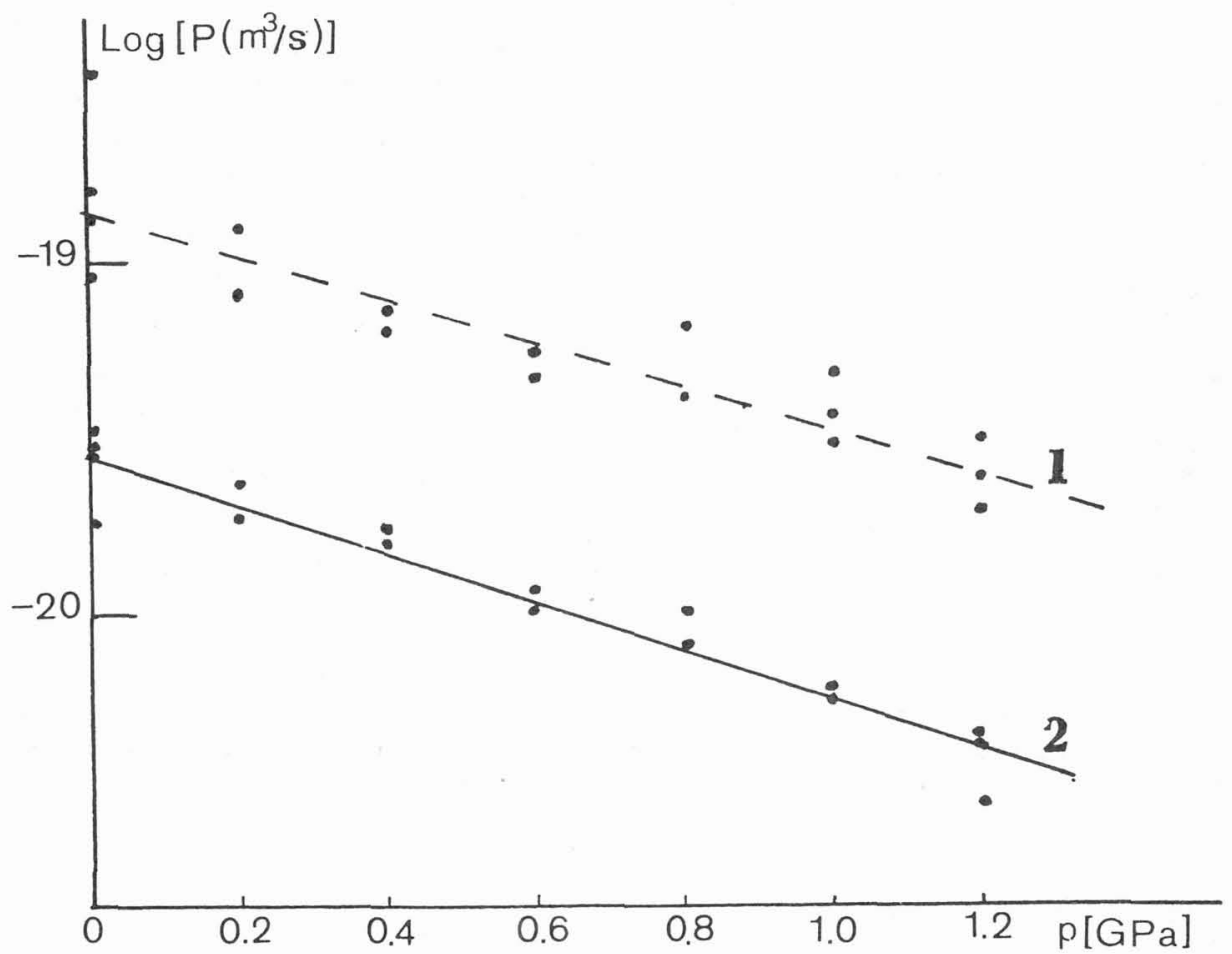

Fig.2 Effect of high pressures on diffusion of $Z_{\mathrm{n}}$ tracer along grain boundaries (Iine 1) and subboundaries (Iine 2) in Al in the B-kinetic regime (after ref.6). Annealing temperature: $593 \mathrm{~K}$. 
Investigations of the effect of high pressure on GBD in Aluminium (6)

The purpose of those investigations was to measure the activation volume for grain boundary diffusion of $Z n$ along general grain boundarles and subboundaries in aluminium. Those data are supposed to be relevant for grain boundary selfdiffusion as well (6). Classical radiotracer methods were used and the high pressure equipment was the same as in the case of GBM studies. The experimental methods and results are given in detail in ref, ( 6 ). Fig. 2 displays the effect of bigh pressure on diffusion along both types of boundaries. The activation volume for GBD in general boundaries was $0.80+1-0.1 \Omega$ while in subboundaries it was $0.86+/-0.06 \Omega$.

\section{Discussion}

The above presented results consist a first approach to a comprehensive study of the effect of high pressures on the atomic mobility in grain boundaries of various types in one metal. The obtained values of activation volumes for GBM and GBD are consistent with results measured by various methods for metals (2,3,7). In fact, Martin et all (3) obtained the value $V^{: *} \approx 1.1+1-.2 \Omega$ for $G B D$ in an indefined boundary in silver. On the other hand, Hahn and Gleiter (2) stated no effect of high pressure on the activation energy of GBM in cadmium. As far as recrystallization and recovery is concerned, V*: for those process in copper was found to be of the order of the atomic volume (7).

Therefore, the above presented data form a consistent pattern indicating that despite similar activation energies for GBD and GBM (8), different defects are controlling those processes. In the case of GBD, it seems that the presence in the boundary of thermally activated vacancles 15 indispensable for atomic motion parallel to boundaries and subboundarles, in agreement with general conclusions concerning dominating GBD mechanisms (9).

As far as GBM is concerned, week pressure dependence of atomic jumps across the boundary indicates that this process occurs rather by an Interstitial than vacancy mechanism. The activation volume for interstitials is smaller than for vacancies (or negative) (1). However, that result can be explained as well in terms of structural porosity controliing grain boundary mobility, as suggested in ref (2) or in terms of GBD being controlied by grain boundary dislocation climb while GBM by their giide.

Irrespectively on the migration mechanism, vacancy drag effects on migrating grain boundaries seem to play a less significant role than theoretically predicted $(10,11)$

\section{Conclustons}

The formation and migration volume for defects controling atomic mobility perpendicular to the boundary is significantly. Iess than of those controling diffusion along boundarles.

\section{Acknowledgments}

This work was supported by the Offlce for Research and Development (Poland) under contract CPBR 2.4 


\section{References}

1.N.L.Peterson, "Diffusion under high pressures" in "Diffusion in Metals and alloys", Diffusion Defect Monograph Series No.7, Eds.F.J.Kedves, D. L. Beke, Trans. Tech. Pub1., p. 134

2. H. Hahn, H. Gleiter, Scripta Met. 13, 3, 1979

3. G. Martin, D. A. Blackburn. Y. Adda, phys, st. sol. 23, 223, 1967.

4. W. Lojkowski, M. Skibska, W. Przetakiewicz, J. Wyrzykowski, Materialy XIl Ogolnopolskiej Konferencji Ketaloznawczej, Kozubnik 1987, p.49

5. J.W. Wyrzykowsk1, M.W. Grabsiti, Met. Sci.17, 445, 1983

6. G. Erdélyi, W. Lojkowski, D. L. Beke, I. Godény and F.J.Kedves, Phil. Mag., in press.

7.L.E. Murr, "Interfacial Phenomena in Metals and Alloys", Addison-Wesley Publ. Comp. , 1975

8.0.V. Presnyakova, V. I. Zaytsev, B. P. Fillatov, V. A. Fomchenko, Fiz. Met. Metaloved, 42, 204, 1975

9.R.W. Balluffi, "Grain Boundary Diffusion Mechanisms in Metals", Met. Trans. A, 13A, 1982

10. H. Gleiter, ActaM.et.27, 187,1979

11. Y. Estrin, K. Lücke, Acta Met. 30, 983,1982 